\section{Pacific Northwest}

National Laboratory

Operated by Battelle for the

U.S. Department of Energy

\title{
The Hanford Site 1000-Year Cap Design Test
}

\author{
G.W. Gee* \\ A.L. Ward* \\ C.D. Wittreich** \\ * Pacific Northwest National Laboratory \\ ** CH2MHill Hanford Group, \\ Richland, Washington
}

D ecember 2002

Prepared for the U.S. Department of Energy under Contract DE-AC06-76RL01830 


\title{
The Hanford Site 1000-Year Cap Design Test
}

\author{
G.W. Gee* \\ A.L. Ward* \\ C.D. Wittreich** \\ * Pacific Northwest National Laboratory \\ ** CH2MHill Hanford Group, \\ Richland, Washington
}

D ecember 2002

Prepared for the U.S. Department of Energy under Contract DE-AC06-76RL01830 


\section{Summary}

Surface barrier or capping technology is needed to isolate buried wastes. A successful cap must prevent the intrusion of plants, animals, and man into the underlying waste, minimize wind and water erosion, require minimal maintenance, and limit water intrusion to near-zero amounts. For some sites where wastes are longlived, caps should potentially last a thousand years or more. At the U.S. Department of Energy (DOE) Hanford Site in Washington State, a surface cap with a 1000-year design life was constructed and then tested and monitored for performance under wetting conditions that are extreme for the region. The cap was built in 1994 over an existing waste site as a part of a Comprehensive Environmental Response, Compensation, and Liability Act (CERCLA) treatability test. The above-grade barrier or cap consists of a 2-m-thick silt-loam soil overlying layers (from top down) of sand, gravel, basalt rock (riprap), and a low-permeability asphalt. Two sideslope configurations, a clean-fill gravel on a 10:1 slope and a basalt riprap on a 2:1 slope were part of the overall design and testing. Design considerations included constructability; water-balance monitoring; wind and water erosion control and monitoring; surface revegetation, biointrusion control, subsidence, and sideslope stability; and durability of the asphalt layer.

The barrier was monitored for a period of 8 years to answer specific questions related to stability and longterm performance. One-half of the soil surface was irrigated for 3 years such that the total water applied (including precipitation) was $480 \mathrm{~mm} / \mathrm{yr}$, or three times the long-term annual average. An extreme precipitation event (70 $\mathrm{mm}$ in 8 hours), representing a 1,000-year return storm for Hanford, was applied in late March of the first 3 years when soil water storage was at a maximum. Evapotranspiration annually removed virtually all of the incident water (precipitation plus irrigation) in spite of record precipitation in 2 of the 8 test years. There was never any drainage from the silt-loam cover under non-irrigated conditions. Under irrigated conditions, during the third year, one of four silt loam tests drained slightly but did not exceed the design limit of $0.5 \mathrm{~mm}$. In contrast, all the protective sideslopes had substantial drainage. However, the quantities were much less than expected, particularly for the riprap sideslope. Low drainage from riprap was attributed to thermal heating and advective drying of the dark-colored basalt rock. After the first year of testing, there was no measurable wind erosion, and runoff was small, occurring only twice, in winters when there was frozen ground and rapid snowmelt. Limited erosion was attributed to extensive revegetation of the soil surface. The sideslopes and soil cover have remained stable. The riprap sideslopes remain barren while there has been a slow but persistent increase in vegetation on the gravel sideslopes. The performance data to date support deployment of the Hanford cap design at sites where 1000-year protection is required. 


\section{Contents}

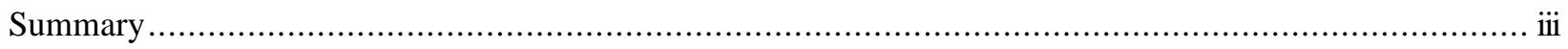

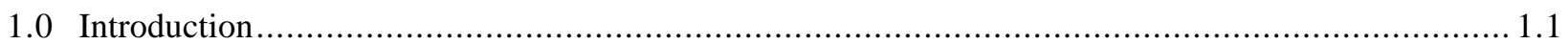

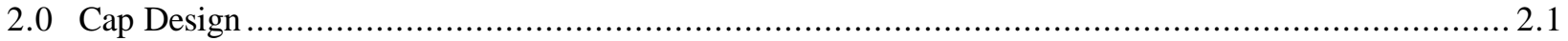

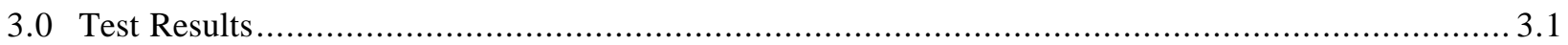

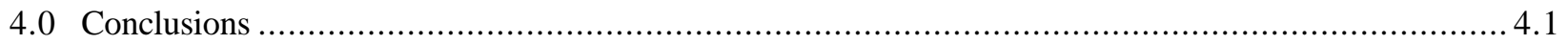

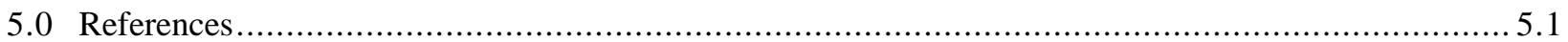

\section{Figures}

2.1. Hanford Surface Barrier (cap) -Development Tasks

2.2. Hanford Prototype Cap (1000-year cap) Cross Section Showing (a) Interactive

Water Balance Processes, (b) Gravel Sideslope, and (c) Basalt Rip-Rap Sideslope......................... 2.2

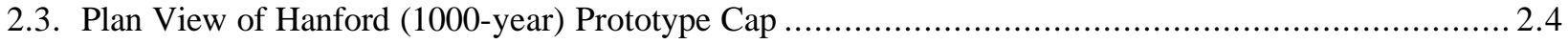

3.1. Cumulative Precipitation for the Hanford Cap Test ............................................................... 3.1

3.2. Temporal Variation in Mean Soil Water Storage at the Hanford Prototype 1000-Year

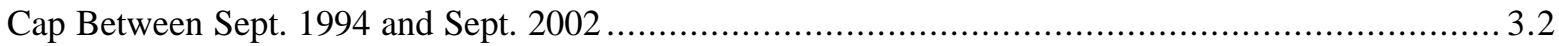

3.3. Cumulative Drainage from Sideslopes Compared to Irrigated Silt-Loam Drainage at the Hanford (1000-year) Cap Test During the First 4 Years of Testing

\section{Table}

3.1. Seasonal Precipitation for the Hanford Site, 1994 through 2002 


\subsection{Introduction}

The U.S. Department of Energy (DOE) has been actively developing surface-barrier (cap) technology at the Hanford Site for over two decades (Adams et al. 1981; Wing and Gee 1994; Ward and Gee 2000; Galgoul and Sump 2002; Link et al. 1995). A multi-year barrier-development program was started at Hanford in 1985 to develop, test, and evaluate the effectiveness of various cap designs (Wing 1993). A series of over 130 reports documents the progress of the barrier development work (see, http://hanfordbarriers.pnl.gov/). These reports detail field tests, natural analog studies, and modeling of cap performance and provide information on water balance, wind and water erosion, and biotic-intrusion studies supporting cap development at the Hanford Site. This paper details testing specifically designed for 1000-year barrier performance and describes current research activities at a prototype cap at the Hanford Site. Pacific Northwest National Laboratory and $\mathrm{CH} 2 \mathrm{M}$ Hill conducted this research at the request of DOE. Results of these tests can be used to support the application of 1000-year barriers on sites with similar environments as found at the Hanford prototype surface barrier (or cap). For purposes of this paper, surface barrier and cap will be used interchangeably.

This report provides details of the cap design and gives the test results of monitoring precipitation and drainage from 1994 through 2002. 


\subsection{Cap Design}

Figure 2.1 shows the scope of work undertaken during the past 17 years that has been leading toward a final cap design. As part of the overall development effort, a prototype barrier, incorporating all essential elements of a long-term surface barrier, was constructed at the Hanford Site in 1994.

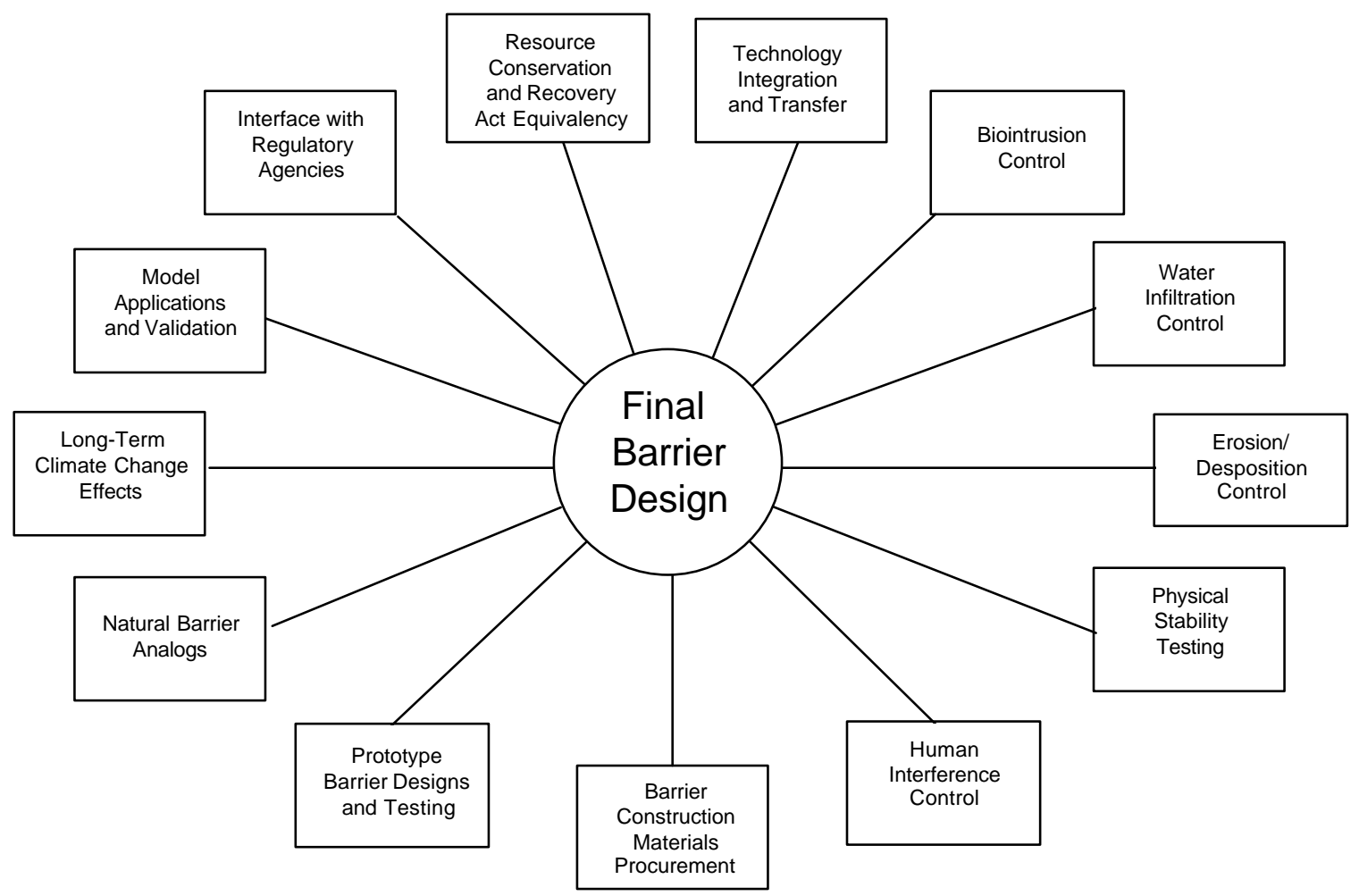

Figure 2.1. Hanford Surface Barrier (cap) -Development Tasks

Because of the demand for a cap that could perform for at least 1,000 years without maintenance, natural construction materials, for example, fine soil, sand, gravel, cobble, basalt riprap, and asphalt, were selected to optimize cap performance and longevity. Most of these natural construction materials are available in large quantities on the Hanford Site and are known to have existed in place for thousands of years, for example, basalt. The current cap consists of a fine-soil layer overlying other layers of coarser materials, such as sands, gravels, and basalt riprap, and is designed to limit recharge to $<0.5 \mathrm{~mm} / \mathrm{yr}$ (Figure 2.2). 


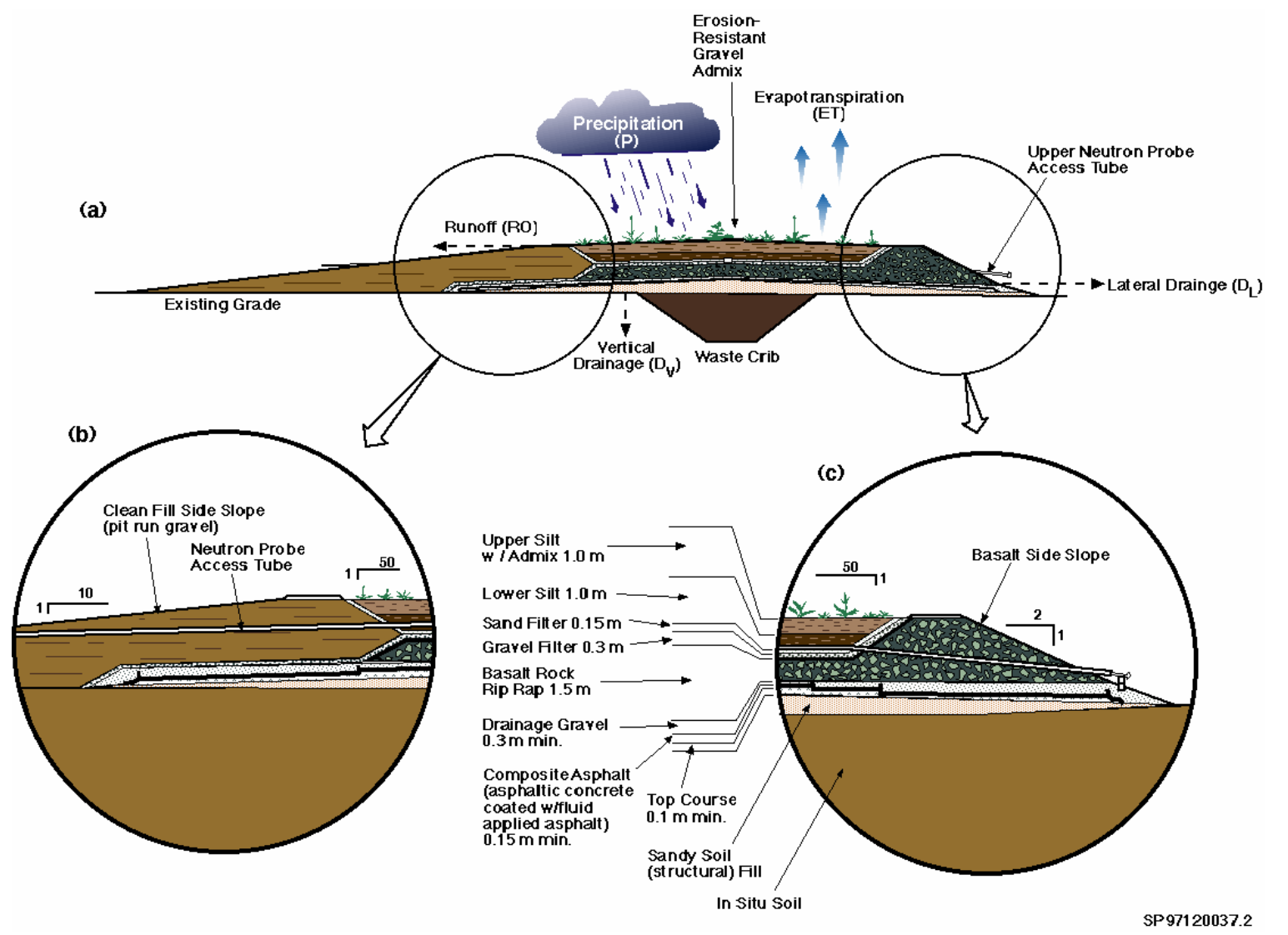

Figure 2.2. Hanford Prototype Cap (1000-year cap) Cross Section Showing (a) Interactive Water Balance Processes, (b) Gravel Sideslope, and (c) Basalt Rip-Rap Sideslope

Each layer serves a distinct purpose. The fine-soil (silt) layer acts as a sponge or reservoir in which moisture is stored until the processes of evaporation and transpiration (ET) recycle any excess water back to the atmosphere. The fine-soil layer also provides the medium for establishing plants that are necessary for transpiration to take place. The coarser materials (sand, gravel, rock) placed directly below the fine-soil layer create a capillary break that inhibits the downward percolation of water through the barrier. The placement of fine soils directly over coarser materials also creates a favorable environment that encourages plants and animals to limit their natural biological activities to the upper, fine-soil portion of the barrier, thereby reducing biointrusion into the lower layers. The coarser materials also help to deter inadvertent human intruders from digging deeper into the cap profile. Low-permeability (composite asphalt) layers, placed in the cap profile below the capillary break, also are used in the barrier. The purpose of the low-permeability layers is (1) to divert away from the waste zone any percolating water that crosses the capillary break and (2) to limit the upward movement of noxious gases from the waste zone. The coarse materials located above the lowpermeability layers serve as a drainage medium to channel any percolating water horizontally to the edges of the barrier.

In addition to testing the performance of a capillary cap design, the prototype is being used to test two different sideslope designs: (1) a relatively flat apron (10:1, horizontal: vertical) of pit-run gravel and (2) a relatively steep (2:1) embankment of fractured basalt riprap (Gee et al. 1993b; Ward and Gee 1997). Figure 2.2 also shows details of the two sideslope configurations used in the prototype barrier. A shrub and grass 
cover was established on the fine-soil surfaces of the prototype in Nov. 1994. Shrubs were planted at a density of two plants $/ \mathrm{m}^{2}$ with four sagebrush (Artemisia tridentata) plants to every one rabbitbrush (Chrysothamnus nauseosus) plant.

Designing a maintenance-free cap requires an understanding of how natural processes affect cap performance. A series of tests was designed to provide a better understanding of these processes and enable the design of a cap that passively meets performance objectives.

A simplified water balance equation for the 1000-year prototype cap can be written as follows:

$$
P-D-D P-R-\Delta W-E T=0
$$

where $\quad \mathrm{P}=$ natural precipitation

$\mathrm{D}=$ drainage out of the soil cover (diverted by asphalt)

$\mathrm{DP}=$ deep percolation (vertical drainage past the asphalt layer)

$\mathrm{R}=$ surface runoff

$\Delta \mathrm{W}=$ change in soil water storage

$\mathrm{ET}=$ evapotranspiration

ET is the only component not measured, but is calculated by solving Equation 1:

$$
E T=P-(D+D P+R+\Delta W)
$$

The change in storage, $\Delta \mathrm{W}$, is calculated as the difference in $\mathrm{W}$ measured at different times. Soil water storage $\mathrm{W}$ is calculated from measurements of soil water content, $\theta$, by integrating $\theta$ over depth profiles. Thus, $\mathrm{W}$ between the surface and depth $z$ is calculated as follows:

$$
W=\int_{0}^{L} \theta(z) d z \approx L_{1} \theta_{1}+\sum_{i=1}^{n-1} L_{i+1} \frac{\left(\theta_{i}+\theta_{i+1}\right)}{2}
$$

where $\quad \mathrm{L}=$ total depth of characterization $(2 \mathrm{~m})$

$\theta_{1}=$ volumetric soil water content at the first measurement point

$\mathrm{L}_{1}=$ distance from surface to first measurement point

$\mathrm{n}=$ number of measurement points

$\theta_{\mathrm{i}}=$ volumetric soil water content at the $i^{\text {th }}$ depth in the profile

$\mathrm{L}_{\mathrm{i}}=$ distance between successive measurement points.

Water-balance monitoring of the surface cap was carried out using rain gages to measure irrigation and precipitation inputs, neutron probe for soil water content (water storage), and pan or basin-type lysimeters for drainage collection. The lysimeters were built during construction of the cap by placing curbing on the asphalt layer and creating 12 collection zones. The largest lysimeter area is $322 \mathrm{~m}^{2}$. Piping carries the drainage water from each collection zone to a stilling basin where it is monitored with a resolution of a few 
liters or less (i.e., less than $0.1 \mathrm{~mm}$ ). Figure 2.3 shows a plan view of the cap surface and the collection zones, six each for irrigated (north end) and nonirrigated (south end) areas. Details of the monitoring are described elsewhere (Ward and Gee 1997; DOE 1999).

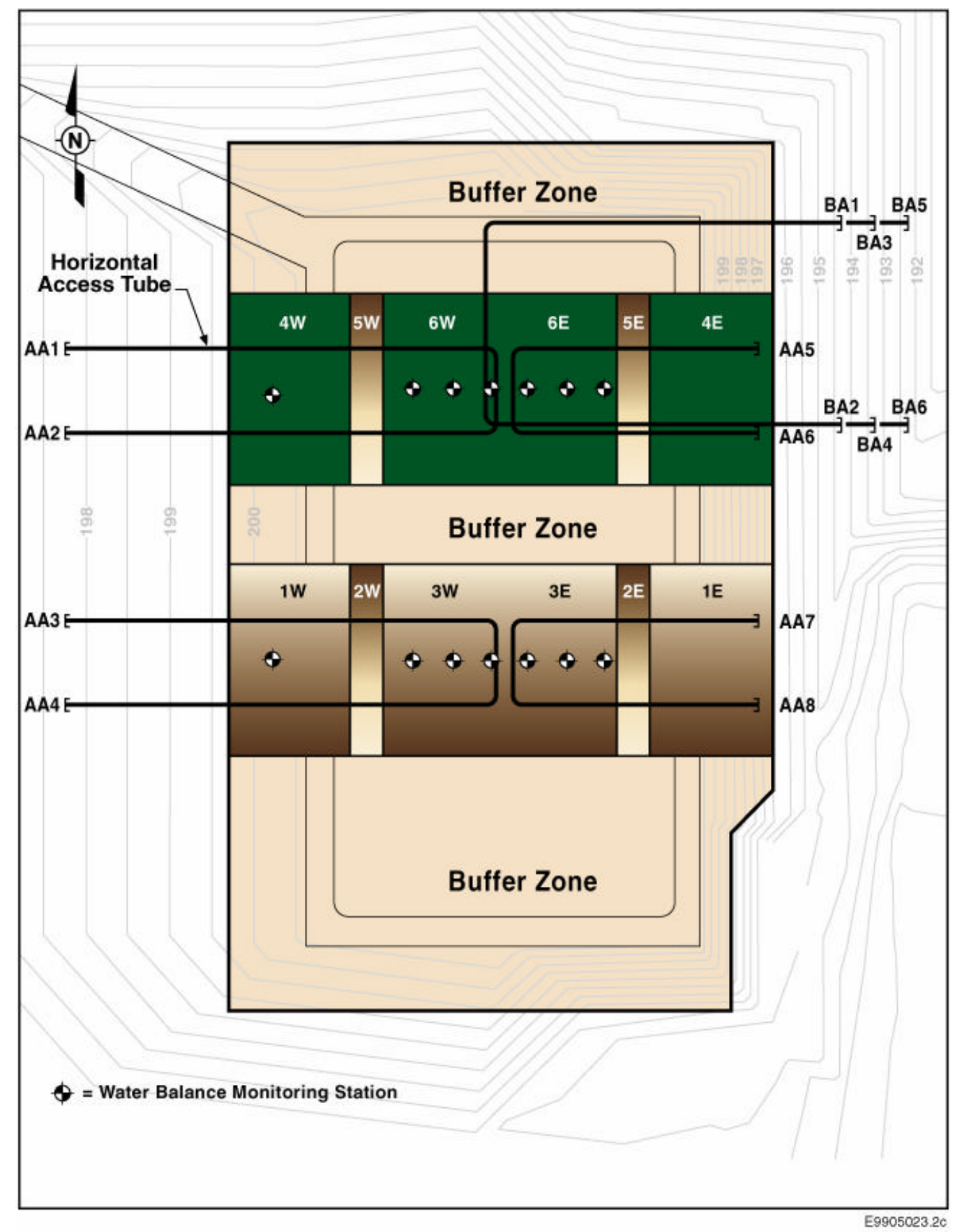

Figure 2.3. Plan View of Hanford (1000-year) Prototype Cap. Twelve individual collection areas for irrigated (north) side and nonirrigated (south) side of the cap are represented by the designations $1 \mathrm{~W}$ through $6 \mathrm{E}$. Water-balance monitoring stations are shown for each test area as well as horizontal neutron probe access tubes for monitoring below the silt loam and asphalt layers. 


\subsection{Test Results}

From Nov. 1994 through Oct. 1997, fine soil over sand (capillary barrier) plots on the northern half of the prototype cap were subjected to an irrigation regime of three times the long-term average annual precipitation (3X). Figure 3.1 shows the cumulative water application (irrigation plus precipitation for the 8-year test).

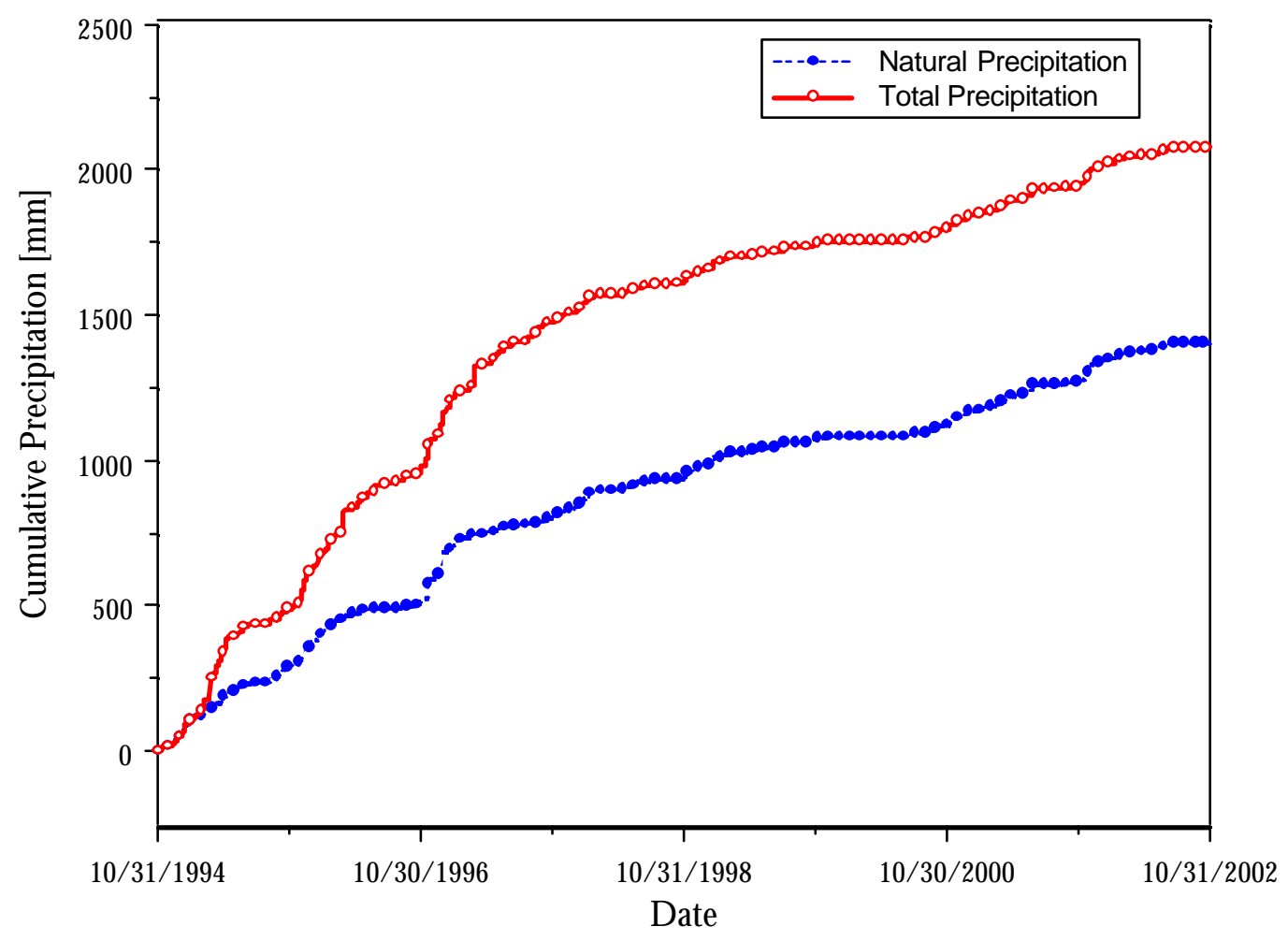

Figure 3.1. Cumulative Precipitation for the Hanford Cap Test. Solid circles are cumulative natural (ambient) precipitation. Open circles are total precipitation (irrigation plus precipitation). Irrigation continued for 3 years (1995 through 1997).

The irrigation treatment included applying sufficient water on 1 day during the last week of March for 3 years (1995 through 1997) to mimic a 1000-year storm event (70 $\mathrm{mm}$ of water) and periodic applications to achieve a precipitation target of $480 \mathrm{~mm} / \mathrm{yr}$ for the entire water year (Nov. 1 through Oct. 31). The survival rate of the transplanted shrubs has been remarkably high; 97\% for sagebrush and 57\% for rabbitbrush (Gee et al. 1996). Heavy invasions of tumbleweed (Salsola kali) occurred in 1995 but were virtually absent in 1996. Grass cover, consisting of 12 varieties of annuals and perennials (including cheatgrass, several bluegrasses, and bunch grasses), dominated the surfaces, particularly those that were irrigated. There was a surface response to irrigation, with nearly twice as much grass cover on the irrigated surfaces compared to the nonirrigated surfaces (Gee et al. 1996). After irrigation stopped, approximately $75 \%$ of the surface was covered by vegetation, a cover value typical of shrub-steppe plant communities. In all respects, the vegetated cover appeared to be healthy and normal. 
Figure 3.2 compares temporal changes in mean water storage for the fine-soil layer on the irrigated and nonirrigated treatments at the prototype cap for 8 years (Sept. 1994 through Sept. 2002).

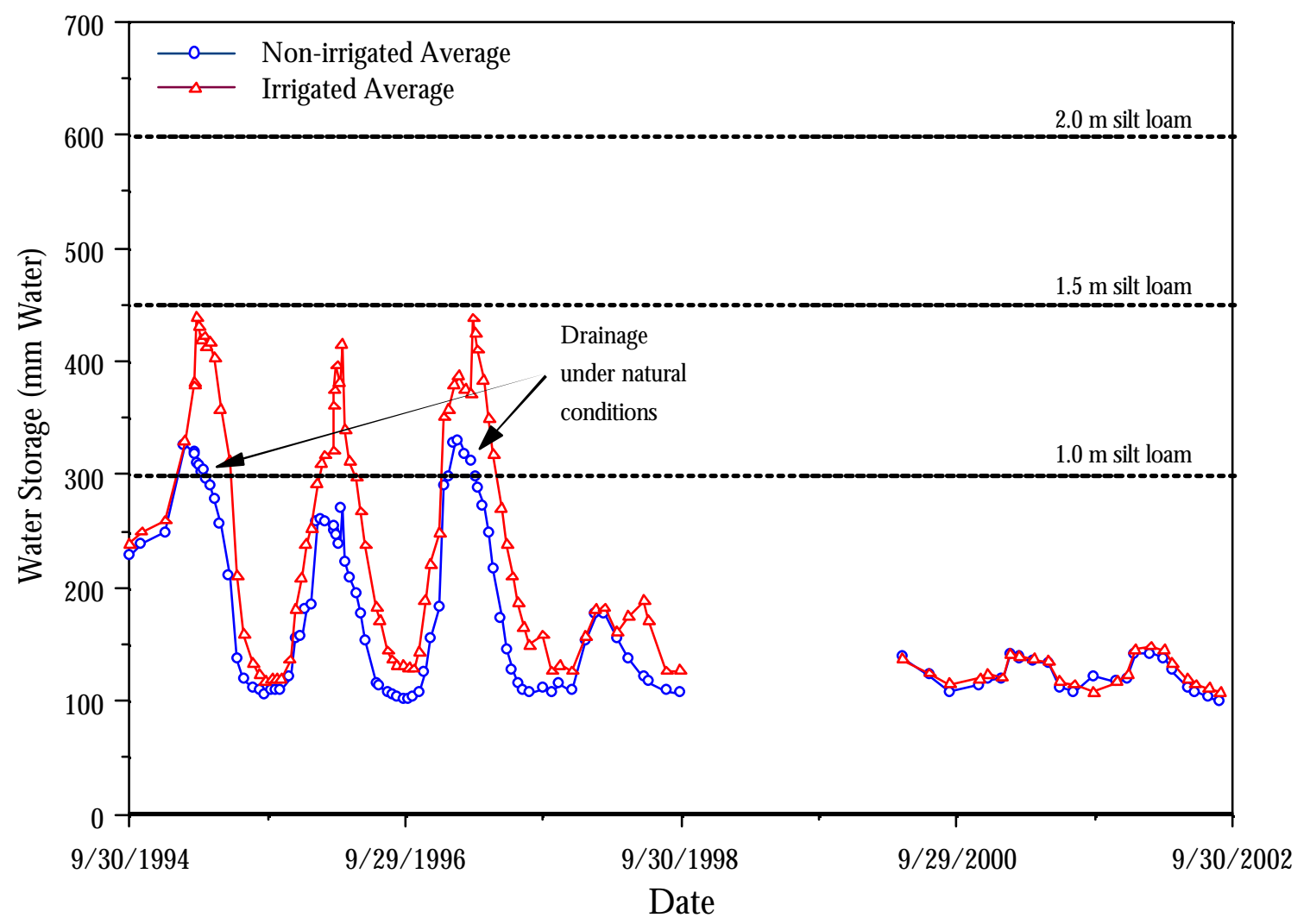

Figure 3.2. Temporal Variation in Mean Soil Water Storage at the Hanford Prototype 1000-Year Cap Between Sept. 1994 and Sept. 2002. Monitoring after Sept. 1998 was interrupted for more than a year and resumed in 2000. Horizontal dashed lines represent estimated storage capacities for caps with 2-m, 1.5-m, and 1.0-m thick silt-loam surfaces.

All irrigation and natural precipitation plus all available stored soil water was removed via ET during the first year on the fine-soil surface. This process was repeated so that over the remaining years, water was annually removed from the entire soil profile by late summer. ET was effective in preventing all but a minute amount of drainage from one irrigated plot after three years of the wettest treatment, as will be discussed later. There was a hiatus of water-storage monitoring between Sept. 1998 and May of 2000, so no data are available for that time period. However, the trends before and after clearly show that ET was effective in keeping the water storage well below the estimated drainage limit of $600 \mathrm{~mm}$ for the 2-m silt-loam layer. The upper limit of water storage was based on an estimated field capacity of 0.3 for the silt loam soil. Thus, the water stored in $1.5 \mathrm{~m}$ is reduced to $450 \mathrm{~mm}$ and to $300 \mathrm{~mm}$ for a $1.0-\mathrm{m}$ thick soil as shown in Figure 3.2. Soil water content in both irrigated and non-irrigated plots reached a relatively uniform lower limit of 5 to $8 \mathrm{vol} \%$ throughout the soil profile by September of each year. Correspondingly, water storage was reduced to levels of 100 to $150 \mathrm{~mm}$, i.e., the lower-limit of plant-available water, for both the irrigated and non-irrigated soil surfaces. 
The amount of water stored in the fall, within the 2-m silt-loam soil cap, is about one-fifth the amount of water required for drainage. This suggests that extreme winter precipitation, the prime cause of drainage at Hanford, can be readily stored in the fine-soil profile until spring when it is subsequently extracted from the soil by ET. Considering the irrigation treatment to represent the extreme in wet climate, the 2-m-thick soil cover would not be expected to drain, even under the wettest Hanford climate conditions. If the cover thickness were reduced from $2 \mathrm{~m}$ to $1.5 \mathrm{~m}$, it appears that little or no drainage would be expected. However, if the cover were reduced to $1 \mathrm{~m}$, it appears that under irrigated (extreme wet) conditions, the soil would be expected to drain, as indicated in Figure 3.2.

Table 3.1 shows the seasonal precipitation for the past 8 years at the Hanford Meteorological Station a few $\mathrm{km}$ from the prototype cap. These data represent the precipitation input on the cap surface. Two of the 8 years (1995 and 1996) had record precipitation (both in excess of $300 \mathrm{~mm}$ ). Even if these 2 years had repeated themselves over the remaining 6 years, it is unlikely that the 2-m thick soil cap would have drained. However, based on observed storage changes (Figure 3.2) for the nonirrigated area, it appears that drainage would have occurred in 1995 and 1997 (wettest years) if the cap were reduced in thickness to a 1-m depth of silt loam. This supports the case for designing a cap with sufficient water-storage capacity to ensure that under extreme conditions, the cap will still perform adequately.

Table 3.1. Seasonal Precipitation for the Hanford Site, 1994 through 2002

\begin{tabular}{|c|c|c|c|c|c|}
\hline \multirow[b]{2}{*}{ Year } & \multicolumn{5}{|c|}{ Precipitation (mm) } \\
\hline & Total & Winter ${ }^{(\mathbf{a})}$ & Spring $^{(\mathbf{b})}$ & Summer ${ }^{(c)}$ & Autumn $^{(d)}$ \\
\hline 1995 & 313 & 106 & 83 & 30 & 69 \\
\hline 1996 & 310 & 126 & 48 & 5 & 96 \\
\hline 1997 & 162 & 138 & 35 & 18 & 57 \\
\hline 1998 & 164 & 69 & 28 & 22 & 42 \\
\hline 1999 & 95 & 52 & 10 & 24 & 19 \\
\hline 2000 & 205 & 58 & 58 & 18 & 56 \\
\hline 2001 & 172 & 35 & 43 & 36 & 55 \\
\hline 2002 & N/A & 48 & 16 & 21 & N/A \\
\hline $\begin{array}{c}\text { Long-Term } \\
\text { Average }\end{array}$ & 172 & 66 & 38 & 25 & 45 \\
\hline $\begin{array}{l}\text { (a) Dec. of pre } \\
\text { (b) March-Ma } \\
\text { (c) June-Aug. } \\
\text { (d) Sept.-Nov. }\end{array}$ & $\begin{array}{l}\text { ear }+\mathrm{J} \\
\text { rrent ye } \\
\text { ent yea } \\
\text { rent yea }\end{array}$ & $\begin{array}{l}\text { Feb. of cur } \\
\text { terest. } \\
\text { rest. } \\
\text { erest. }\end{array}$ & year of inte & & \\
\hline
\end{tabular}


The positive response of the cap in its capability to remove water and limit drainage demonstrates the continued benefits of having vegetation on the surface. ET for the irrigated plots was nearly double that for the non-irrigated (ambient) plots, suggesting that vegetation is capable of adjusting to water applications. It is apparent that the capacity of vegetation for water consumption was not exceeded even at the $3 \mathrm{X}$ precipitation rates. This further supports the hypothesis that the combination of vegetation and soil storage capacity is more than sufficient to remove all applied water under the imposed test conditions. Within a year after the irrigation was terminated, the water storage in the irrigated and nonirrigated plots became similar. During the past 2.5 years, the water storage in all soil plots was virtually the same (Figure 3.2).

Drainage did not occur from the soil-covered part of the prototype cap until the third year, and then only a small amount (less than $0.2 \mathrm{~mm}$ ) for one of the soil plots was subjected to the $3 \mathrm{X}$ irrigation treatment. No additional drainage has occurred from this silt-loam covered collection area (6E, Figure 3.3), so the total drainage over the 8 years of testing is less than $5 \%$ of the prescribed limit of $0.5 \mathrm{~mm} / \mathrm{yr}$. The drainage was attributed to lateral flow from water diverted off an adjacent roadway. These observations from the prototype cap agree with the results of extensive lysimeter testing of capillary-cap designs (Campbell et al. 1990; Gee et al. 1993b) and suggest that the water-storage capacity of the 2-m-thick, silt-loam layer is in excess of the $3 \mathrm{X}(480-\mathrm{mm})$ precipitation. In contrast, both sideslope configurations drained, although the amount of drainage was significantly less than predicted, based on lysimeter testing with coarse materials (Gee et al. 1993a).

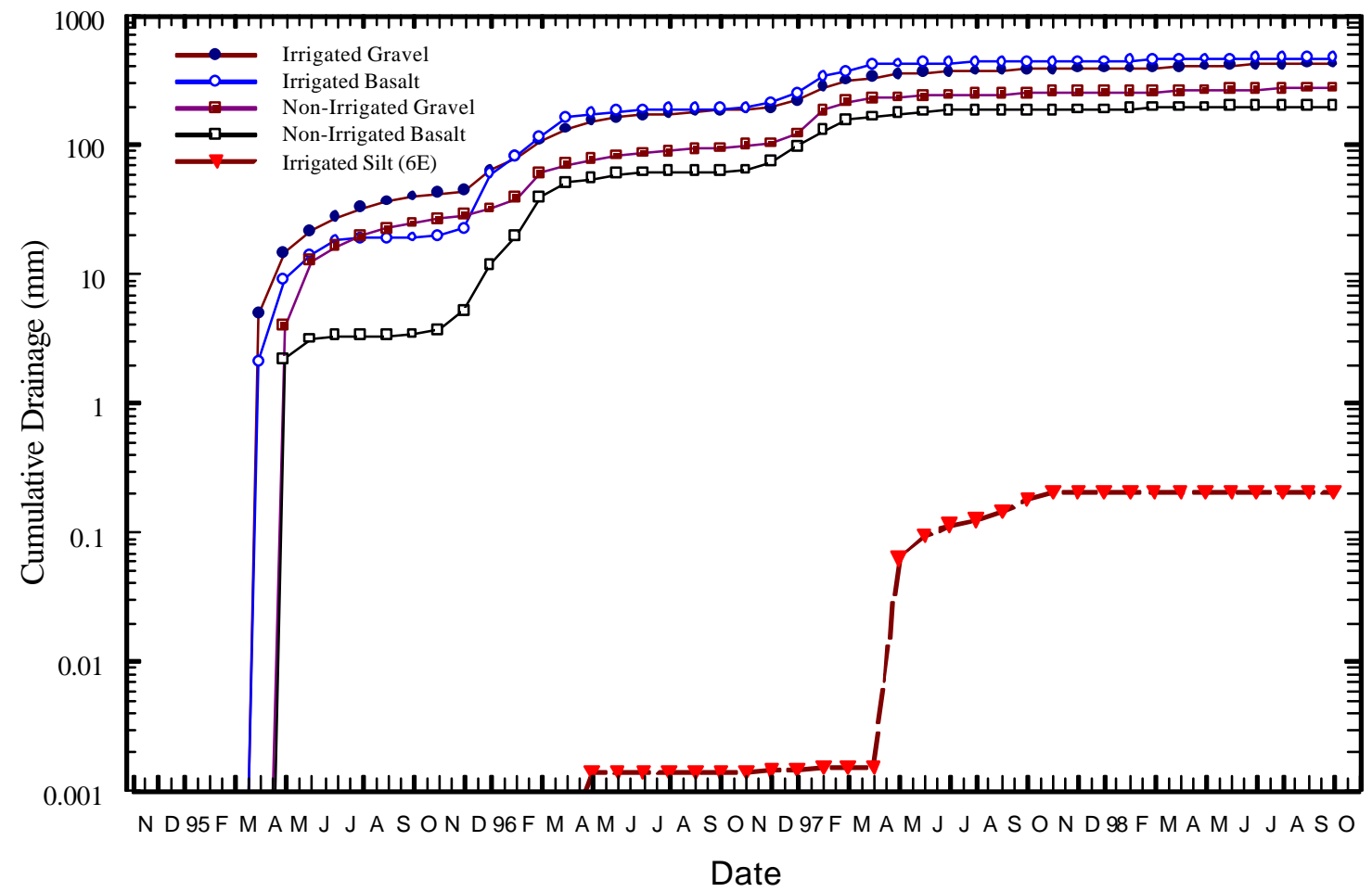

Figure 3.3. Cumulative Drainage from Sideslopes Compared to Irrigated Silt-Loam Drainage at the Hanford (1000-year) Cap Test During the First 4 Years of Testing 
Sideslope drainage was expected since the surfaces are coarse and bare with no vegetation growing on the basalt riprap and only a sparse (less than 10\%) cover growing on the clean-fill gravel (Gee et al. 1993a; Sackschewsky et al. 1995). Figure 3.3 compares cumulative drainage from the gravel and riprap slopes through Oct. 1998. On the nonirrigated treatments, the total amount of drainage from the clean-fill sideslope was greater than that from the basalt riprap sideslopes. A similar trend was observed on the irrigated slopes up until Nov. 1995. While irrigation of the silt-loam surfaces started in February 1995, direct irrigation applications to the sideslopes did not start until Nov. 1995, when the irrigation system was modified to apply water directly to the sideslope plots at the same rates as applied to the silt-loam surfaces. A closer look at these results shows a seasonal dependence of drainage. While drainage from the clean-fill gravel sideslope was continuous, there was essentially no drainage from the riprap in the summer. In the winter, both sideslope configurations drained at similar rates. These trends have continued through 2002. It is our hypothesis that advective drying similar to that described by Stormont et al. (1994) and Rose and Guo (1995) and recently tested by Albrecht and Benson (2002) may be partly responsible for the lower drainage on the riprap sideslopes and may also have an effect on water storage in the fine-soil layer. Additional testing and numerical modeling will be helpful in testing this hypothesis.

Horizontal neutron logging confirmed that water is not accumulating or moving horizontally under the asphalt pad. However, drainage from the gravel and rock sideslopes in contact with the asphalt layer does move horizontally and can run off the edge of the asphalt. Details of the observed shedding of lateral drainage can be found in Ward and Gee (1997) and DOE (1999). The asphalt layer appears to be successful in diverting drainage water and extending the overall footprint or effective area of the cap (i.e., beyond the area of the siltloam surface). What is not determined at this time is the absolute longevity (durability, etc.) of the asphalt, though the expectation is that buried asphalt could last 1000 years or more. Studies of durability testing of asphalt have been proposed but have not been completed.

The rapid establishment of vegetation on the silt loam surface of the cap was thought to be responsible for at least three positive benefits to cap performance. First, the vegetation was dominant in the water-removal process from the soil surfaces. Second, the surface was stabilized against water erosion and runoff. Runoff from the 1000-year storm in 1995 was $1.8 \mathrm{~mm}$ (about $2 \%$ of the $70 \mathrm{~mm}$ applied). There was no runoff in 1996. The improvement was attributed to plant establishment and vegetative growth. Freeze-thaw action, pedoturbation, and root growth have caused changes in soil-bulk density near the surface. Also, an increase in soil organic-matter content near the surface could have enhanced permeability. Finally, there has been a positive benefit in controlling wind erosion. After plant establishment in Nov. 1994, there have been no measurable losses of soil from the surface of the prototype by wind erosion. This is attributed to the vegetation and lack of surface disturbance since the cover was established. Silt loam, gravel, and rock surfaces were found to be stable, and for the 8-year test-period, subsidence was not observed.

Eight years of testing provide important but limited information for long-term barrier-performance estimates. Because only a finite amount of time exists to test a cap that is intended to function for a minimum of 1,000 years, the testing program has been designed to "stress" the prototype so that cap performance can be determined within a reasonable time frame. To date, the results are very encouraging and support the premise that a cap can be subjected to extreme stresses, for example, 1000-year storms, and still perform successfully. Continued monitoring of prototype cap performance for extended periods is desirable because the succession of vegetation, the full development of root profiles, and the natural colonization of the cap surface by burrowing animals will occur over a longer time period. Continued monitoring of the prototype 
cap will be a valuable asset for hydrologic model-validation studies and in the assessment of the long-term performance of cover systems at the Hanford Site. 


\subsection{Conclusions}

The study of surface barriers at the Hanford Site has evolved into an integrated demonstration of key features of a 1000-year cap designed to minimize water intrusion, erosion, and biointrusion. The results of field tests, experiments, and lysimeter studies provide baseline information upon which cap designs can be based. Test results show that for the Hanford Site's arid climate, a well-designed capillary cap limits drainage to near-zero amounts. A subsurface asphalt layer provides additional redundancy. Data collected under extreme conditions (excess precipitation) provides confidence that the cap has the capability to meet its performance objectives for the 1,000-year design life. Data from the prototype cap confirm earlier observations with lysimeters and field plots and show that virtually all available water can be removed from the soil surfaces by ET under the tested elevated precipitation conditions. Sideslopes, in contrast, drain because they are barren. The sideslope drainage is less than predicted because of advective heating and wind action but is still significant to warrant consideration during design, particularly where there are adjacent waste sites with underlying contaminant plumes in a deep vadose zone. Asphalt sub-layers can be successful in extending areas of surface protection and can divert drainage water away from underlying wastes, but the durability of the asphalt must be evaluated. 


\subsection{References}

Adams MR, RA Carlson, and PK Brockman. 1981. Long-Term In Situ Disposal Engineering Study, RHOCD-1142, Rockwell, Hanford Operations, Richland, WA.

Albrecht BA, and CH Benson. 2002. "Predicting Airflow Rates in the Coarse Layer of Passive Dry Barriers." J. Geotech. Geoenviron. Eng. 128(4):338-346.

Campbell MD, GW Gee, MJ Kanyid, and ML Rockhold. 1990. Field Lysimeter Test Facility: Second Year (FY 1989) Test Results, PNL-7209, Pacific Northwest Laboratory, Richland, WA.

Galgoul MJ, and C Sump. 2002. Alternative Fine-Grained Soil Borrow Source Study Final Report, BHI01551, Rev. 0, Bechtel Hanford, Inc., Richland, WA.

Gee GW, DG Felmy, JC Ritter, MD Campbell, JL Downs, MJ Fayer, RR Kirkham, and SO Link. 1993 . Field Lysimeter Test Facility Status Report IV: FY 1993, PNL-8911, Pacific Northwest Laboratory, Richland, WA.

Gee GW, LL Cadwell, HD Freeman, MW Ligotke, SO Link, RA Romine, and WH Walters, Jr. $1993 \mathrm{~b}$. Testing and Monitoring Plan for the Permanent Isolation Surface Barrier Prototype, PNL-8391, Pacific Northwest Laboratory, Richland, WA.

Gee GW, AL Ward, BG Gilmore, SO Link, GW Dennis, and TK O'Neil. 1996. Hanford Protective Barrier Status Report: FY 1996, PNNL-11367, Pacific Northwest National Laboratory, Richland, WA.

Link SO, NR Wing, and GW Gee. 1995. "The Development of Permanent Isolation Barriers for Buried Wastes in Cool Deserts: Hanford Washington.” J. Arid Land Studies 4:215-224.

Rose AW, and W Guo. 1995. "Thermal Convection of Soil Air on Hillsides.” Environ. Geology 25:258-262.

Sackschewsky MR, CJ Kemp, SO Link, and WJ Waugh. 1995. "Soil Water Balance Changes in Engineered Soil Surfaces," J. Environ.Qual. 24:352-359.

Stormont JC, MD Ankeny, and MK Tansey. 1994. "Water Removal from A Dry Barrier Cover System.” In In-Situ Remediation: Scientific Basis for Current and Future Technologies, G. W. Gee and N. R. Wing (Eds.), pp. 325-346. Parts 1-2. Thirty-Third Hanford Symposium on Health and the Environment. November 7-11, 1994, Pasco, WA, Battelle Press, Columbus, OH.

U.S. Department of Energy (DOE). 1999. 200-BP-1 Prototype Barrier Treatability Test Report. DOE/RL99-11, U.S. Department of Energy, Richland, WA. 
Ward AL, and GW Gee. 1997. "Performance Evaluation of a Field-Scale Surface Barrier." J. Environ. Qual. 26:694-705.

Ward AL, and GW Gee. 2000. "Hanford Site Surface Barrier Technology," pp. 1415-1423. In Vadose Zone Science and Technology Solutions, B. B. Looney and R. W. Falta (Eds.), Battelle Press, Columbus, OH.

Wing NR. 1993. Permanent Isolation Surface Barrier Development Plan, WHC-EP-0673, Westinghouse Hanford Company, Richland, WA. 
PNNL-14143

\section{Distribution}

No. of

Copies

\section{OFFSITE}

Wesley L. Bratton

Vista Engineering

8203 W. Quinault Ave

Kennewick, WA., 99336

2 Lawrence Livermore National Laboratory

L-130

Livermore, California 94550

Attn: William D. Daily

Abe Ramirez

2 Lawrence Berkley National Laboratory

Department of Earth and Planetary Sciences

MS 4767

1 Cyclotron Road

Berkeley, California 94720-4767

Attn: Donald J. DePaolo

Mark Conrad

James B. Fink

HydroGEOPHYSICS, Inc.

5865 South Old Spanish Trail

Tucson, Arizona 85747

Sandra Lilligren

Nez Perce Tribe, ERWM

P.O. Box 365

Lapwai, Idaho 83450

Rosemary J. Knight

Stanford University Mitchell Bldg

Satnford, CA., 94305-2215
No. of

Copies

\section{OFFSITE}

Jan W. Hopmans

Hydrology Program

Department of Land, Air and Water Resources

123 Veihmeyer Hall

University of California

Davis, CA 95616

Peter C. Lichtner

Los Alamos National Laboratory

Environmental Sciences Division (EES-5)

MS F-649

Los Alamos, New Mexico 87545

Brian J. Andraski

U.S. Geological Survey

333 W Nye Ln., Rm. 203

Carson City, NV, 89706

Ernest L. Majer

Lawrence Berkeley National Laboratory

1 Cyclotron Road (MS 90-116)

Berkeley, California 94720

Earl D. Mattson

Idaho National Engineering and Environmental Laboratory

P.O. Box 1625

2251 N. Boulevard

Idaho Falls, Idaho 83415-2107

Gregory A. Newman

Sandia National Laboratories

P.O. Box 5800

MS-0750

Albuquerque, New Mexico 87185-0750

Distr. 1 


\section{Distribution (Contd)}

No. of

Copies

OFFSITE

James B. Sisson

Idaho National Engineering and Environmental Laboratory, BBWI

P.O. Box 1625, MS-2107

Idaho Falls, Idaho 83415-2107

John Baker

USDA-ARS

Department of Soil, Water, \& Climate

439 Borlaug Hall

University of Minnesota

1991 Upper Buford Circle

St. Paul, MN 55108

Alan and Lorrie Flint

US Geological Survey

Placer Hall

6000 J Street

Sacramento CA, 95819-6129

Rien van Genuchten

U.S. Salinity Laboratory

450 West Big Springs Road

Riverside, CA 92507-4617

John Nimmo

U.S. Geological Survey

345 Middlefield Road, MS-421

Menlo Park, CA 94025

Michael H. Young

Div. of Hydrologic Sciences, Desert Research Institute

755 E. Flamingo Road, Las Vegas, NV 89119
No. of

Copies

\section{OFFSITE}

2 Los Alamos National Laboratory

Environmental Science Group

MSJ495

Los Alamos, New Mexico 87545

Attn: Everett P. Springer

Brent Neuman

Carl. I. Steefel

Lawrence Livermore National Laboratory

L-204

P.O. Box 808

Livermore, California 94551

P. J. Wierenga

Soil, Water, and Environmental Science

University of Arizona

Tucson, Arizona 85721

Michael Wilt

EMI

1301 S. $46^{\text {th }}$ St.

UCRFS Bldg. 300

Richmond, California 94804

T.C. Jim Yeh

University of Arizona

Department of Hydrology and Water Resources

The University of Arizona, Bldg. 11

Tucson, Arizona 85721

Distr. 2 


\section{Distribution (Contd)}

No. of

Copies

ONSITE

2 DOE Office of River Protection

C. A. Babel H6-60

R. M. Yasek H6-60

9 DOE Richland Operations Office

B. L. Foley

A6-38

J. P. Hanson

K8-50

R. D. Hildebrand

A5-13

K8-50

H6-60

A5-13

A5-113

H6-60

3 Bechtel Hanford Inc.

R. L. Biggerstaff

L. R. Curry

K. R. Fecht

16 CH2M Hill Hanford Group

J. W. Cammann

A. J. Knepp

F. M. Mann

D. A. Myers

V. J. Rohay

L. C. Swanson

C. D. Wittreich (10)

2 MACTER-ERS

J. F. Bertsch

B1-42

R. G. McCain

H0-02

H0-19

H0-02

T4-08

H0-22

$\mathrm{H}-022$

H0-22

H0-19

H9-02

H9-03

B1-42
No. of

Copies

ONSITE

3 Waste Management Technical Services

M. G. Gardner

H1-11

J. E. Meisner

H1-11

R. K. Price

H1-11

6 Washington Department of Ecology

F. W. Bond

B5-18

J. Caggiano

B5-18

D. Goswami

B5-18

A. Huckaby

B5-18

S. Leja

B5-18

N. H. Uziemblo

B5-18

1 U.S. Environmental Protection Agency

D. A. Faulk

B5-01

\section{$5 \quad$ Fluor Federal Services}

R. J. Fabre

$\mathrm{X} 5-50$

B. H. Ford

E6-35

R. Jackson

E6-35

R. Khaleel

E6-17

R. T. Wilde

E6-35 


\section{Distribution (Contd)}

No. of

Copies

ONSITE

62 Pacific Northwest National Laboratory

B. Barnett

K6-81

W. F. Bonner

K9-14

R. W. Bryce

E6-35

R. E. Clayton

P8-37

P. W. Eslinger

K6-80

M. J. Fayer

K3-33

M. D. Freshley (2)

H0-21

G. W. Gee (15)

K9-33

J. O. Goreham

K9-33

T. J. Gilmore

K6-81

D. G. Horton

K6-81

J.M. Keller

K9-36

C. T. Kincaid

K9-33

G. V. Last

K6-81

P. E. Long

K9-33

W. J. Martin

K3-54

P. D. Meyer

BPO

C. J. Murray

K6-81

S. M. Narbutovskih

K6-96

Mart Oostrom

K9-33

W. E. Nichols

K9-33

S. P. Reidel

K6-81

M. L. Rockhold

K9-33

R. J. Serne

K6-81

C. E. Strickland

K9-36

M. D. Sweeney

K6-81

M. J. Truex

K2-10

A. L. Ward (10)

K9-33

K. Waters-Husted

K9-33

M. White

K9-36

B. A. Williams

K6-81

M. D. Williams

K9-36

S. B. Yabusaki

K9-36

J. M. Zachara

K8-96

F. Zhang (2)

K9-33

Technical Report Files (2)

Distr. 4 